\title{
GREEN PROPULSION RESEARCH AT TNO THE NETHERLANDS
}

\author{
Alfons Mayer*, Wolter Wieling* \\ *TNO, The Netherlands Institute for Applied Scientific Research Lange Kleiweg 137 \\ 2288GJ Rijswijk, The Netherlands \\ Alfons.Mayer@tno.nl,Wolter.Wieling@tno.nl
}

\begin{abstract}
This paper describes the recent theoretical and experimental research by the Netherlands Organisation for Applied Scientific Research (TNO) into green replacements for hydrazine, hydrazine derivatives and nitrogen tetroxide, as propellants for in-space propulsion. The goal of the study was to identify propellants that are capable of outperforming the current propellants for space propulsion and are significantly less hazardous for humans and the environment. Two types of propellants were investigated, being monopropellants and bipropellants. The first section of the paper discusses the propellant selection. Nitromethane was found to be the most promising monopropellant. As bipropellant, a combination of hydrogen peroxide (HP) and ethanol was selected, where the ethanol is rendered hypergolic with hydrogen peroxide. The second part of the paper describes the experimental verification of these propellants by means of engine testing. Initiation of the decomposition of nitromethane was found to be problematic, hypergolic ignition of the hydrogen peroxide and ethanol bipropellant however was successfully demonstrated.
\end{abstract}

Keywords: Green propulsion, monopropellant, bipropellant, hydrogen peroxide, nitromethane.

\section{INTRODUCTION}

The use of hydrazine and its derivatives like mono-methylhydrazine (MMH) and unsymmetrical dimethylhydrazine (UDMH) as propellants for in-space propulsion becomes increasingly more difficult. Due to the toxicity and reactivity of these propellants, the costs for fuelling a spacecraft has increased substantially over the years. Furthermore, hydrazine is included on the list of Substances of Very High Concern [1], as part of the Europe's REACH (Registration, Evaluation, Authorisation and restriction of Chemicals) legislation and $\mathrm{MMH}$ has been classified by the European CHemicals Agency (ECHA) as "may cause cancer" [2]. All of this makes the future availability and affordability of these propellants uncertain. Alternatives for hydrazine are already studied across the world, and the interest from industry for these propellants is slowly growing [3].

TNO has a long term commitment to developing green propellant alternatives for space propulsion applications. This paper provides an overview of the theoretical and experimental work performed 
by TNO on developing 'green' replacements for the conventional storable propellants like hydrazine, $\mathrm{MMH}$ and nitrogen tetroxide (NTO). The overall goal of this work was to identify and test propellants that have the potential of outperforming conventional storable propellants, and at the same time, are substantially less hazardous for people and the environment. The first part of this paper discusses the method that was used to identify the most promising 'green' propellant candidates. The second part of the paper describes the experimental work performed by TNO to verify the potential of these propellants by means of engine testing.

\section{DEFINITION OF GREEN PROPELLANTS}

In order to identify the most promising 'green' propellant candidates, a workable definition of a 'green' propellant is required. In all TNO studies, a definition based on the Global Harmonized System (GHS) for Acute Toxicity Classification (ATC) is used. According to this definition, acute toxicity refers to:

"Those adverse effects occurring following oral or dermal administration of a single dose of a substance, or multiple doses given within 24 hours, or an inhalation exposure of 4 hours" [4].

A substance can be allocated to one of five acute toxicity classes, ranging from class 1 (most toxic) to class 5 (least toxic). The toxicity class to which a substance belongs, depends on the approximate Lethal Dose $\left(\mathrm{LD}_{50}\right)$ in case of oral or dermal administration, or the Lethal Concentration $\left(\mathrm{LC}_{50}\right)$ in case of inhalation exposure. The $\mathrm{LD}_{50}$ and $\mathrm{LC}_{50}$ are furthermore defined as the dose (expressed in $\mathrm{mg}$ substance per $\mathrm{kg}$ of subject mass) and concentration (expressed in parts per million in the local atmosphere), required to kill half of a tested population within a certain time ( $24 \mathrm{hrs}$ for dermal and oral administration and $4 \mathrm{hrs}$ for inhalation exposure). An overview of the exposure routes and the corresponding $\mathrm{LD}_{50}$ and $\mathrm{LC}_{50}$ thresholds is given in Table 1 . Table 2 gives the acute toxicity classification for the three most common storable propellants for in-space propulsion, i.e. Hydrazine, $\mathrm{MMH}$ and NTO.

Table 1 Acute Toxicity categories according to the GHS

\begin{tabular}{|c|c|c|c|c|c|}
\hline Exposure route & Class 1 & Class 2 & Class 3 & Class 4 & Class 5 \\
\hline $\begin{array}{c}\text { Oral } \\
\mathrm{LD}_{50}(\mathrm{mg} / \mathrm{kg})\end{array}$ & $\leq 5$ & $\begin{array}{l}>5 \\
\leq 50\end{array}$ & $\begin{array}{l}>50 \\
\leq 300\end{array}$ & $\begin{array}{l}>300 \\
\leq 2000\end{array}$ & $\begin{array}{l}\text { - Anticipated oral } \mathrm{LD}_{50} \text { between } 2000 \\
\text { and } 5000 \mathrm{mg} / \mathrm{kg} \text {; } \\
\text { - Indication of significant effect in }\end{array}$ \\
\hline $\begin{array}{c}\text { Dermal } \\
\mathrm{LD}_{50}(\mathrm{mg} / \mathrm{kg})\end{array}$ & $\leq 50$ & $\begin{array}{l}<50 \\
\leq 200\end{array}$ & $\begin{array}{l}>200 \\
\leq 1000\end{array}$ & $\begin{array}{l}>1000 \\
\leq 2000\end{array}$ & $\begin{array}{l}\text { humans; } \\
\text { - Any mortality at class } 4 ;^{*} \\
\text { - Significant clinical signs at class } 4 ;^{*} \\
\text { - Indications from other studies.* }\end{array}$ \\
\hline $\begin{array}{l}\text { Inhalation } \\
\mathrm{LC}_{50}(\mathrm{ppm})\end{array}$ & $\leq 100$ & $\begin{array}{l}>100 \\
\leq 500\end{array}$ & $\begin{array}{l}>500 \\
\leq 2500\end{array}$ & $\begin{array}{l}>2500 \\
\leq 5000\end{array}$ & $\begin{array}{l}\text { *If assignment to a more hazardous class is } \\
\text { not warranted. }\end{array}$ \\
\hline
\end{tabular}


Table 2 GHS classification of Hydrazine, MMH and NTO

\begin{tabular}{|l|c|c|c|c|c|c|c|}
\hline \multirow{2}{*}{$\begin{array}{l}\text { Administration } \\
\text { route }\end{array}$} & \multicolumn{2}{|c|}{ Hydrazine } & \multicolumn{3}{c|}{ MMH } & \multicolumn{2}{c|}{ NTO } \\
\cline { 2 - 7 } & Value & $\begin{array}{c}\text { GHS } \\
\text { Category }\end{array}$ & Value & $\begin{array}{c}\text { GHS } \\
\text { Category }\end{array}$ & Value & $\begin{array}{c}\text { GHS } \\
\text { Category }\end{array}$ \\
\hline Oral $(\mathrm{mg} / \mathrm{kg})$ & 59 & 2 & 32 & 1 & NA & NA \\
\hline Inhalation $(\mathrm{ppm})$ & 260 & 2 & 34 & 1 & 58 & 1 \\
\hline
\end{tabular}

In the studies performed by TNO, a 'green' propellant was defined as a propellant that falls in an acute toxicity class of 3 or higher. Note that in this definition, the term 'green' is only related to acute toxicity, other parameters like carcinogenicity, mutagenicity and environmental impact are not included in this definition.

In order to differentiate within the group of 'green' propellants (i.e. to assess how 'green' a certain propellant is with respect to other 'green' propellants), a second parameter was defined, the so called the 'Healt Risk Index' (HRI):

$$
\text { HRI }=\sqrt[3]{\frac{\left(\mathrm{P}_{\text {vap }}\right)_{\text {propellant }}}{\left(\mathrm{P}_{\text {vap }}\right)_{\text {ethanol }}}} \times \sqrt{\frac{\left(\left[\frac{\mathrm{LC}_{50}}{\mathrm{P}_{\text {expose }}} \times \frac{1}{\widehat{\mathrm{M}}}\right]\right)_{\text {ethanol }}}{\left(\left[\frac{\mathrm{LC}_{50}}{\mathrm{P}_{\text {expose }}} \times \frac{1}{\widehat{\mathrm{M}}}\right]\right)_{\text {propellant }}}}
$$

The HRI is a dimensionless number with ethanol as a reference. The HRI relates the toxicity of a propellant to actual health risks, which are not only determined by the acute toxicity of the propellant, but also by the probability of exposure in case of a spill. In practice, the most likely administration route during propellant storage and handling is inhalation. Therefore, the exposure probability is determined by the speed with which the concentration of propellant vapours (in ppm) at a certain distance from the spill increases over time. This speed is more or less proportional to the cubic root of the vapour pressure ( $\mathrm{P}_{\text {vap }}$, measure of volatility) of the propellant.

The HRI accounts also for the time it takes until the $\mathrm{LC}_{50}$ value is reached in the body when breathing spilled propellant vapor. This time depends on the $\mathrm{LC}_{50}$ value, the exposure pressure $\left(\mathrm{P}_{\text {expose }}\right)$ and the molar mass ( $\hat{\mathrm{M}})$ of the propellant.

To distinguish between toxicity and suffocation the maximal partial pressure of propellant vapor at which humans can be exposed without being suffocated is defined as $\mathrm{P}_{\text {expose }}$. If the oxygen percentage in air drops below a value of about $10 \%$ breathing becomes irregular and further drop in the oxygen content becomes lethal. A 10\% oxygen concentration in air is obtained if the propellant vapor partial pressure in air reaches a value of $0.52 \mathrm{bar}$. At a higher partial vapor pressure suffocation becomes more lethal than toxicity. The exposure pressure $\left(\mathrm{P}_{\text {expose }}\right.$.) is equal to the vapor pressure for propellants with a vapor pressure up to 0.52 bar. For propellants with a higher vapor pressures the exposure pressure is set to 0.52 bar, because at higher exposure pressures suffocation is dominant in lethality.

A high vapor pressure and molar mass will promote the accumulation of toxic propellant vapours in the ambient air. In order for a propellant to pose a low health risk, the propellant should have a high $\mathrm{LC}_{50}$ value (to limit the toxic effect in case of exposure) and a low vapour pressure and molar mass (to limit the probability of exposure). 
When using the definition in equation (1), the higher the HRI, the higher the health risk posed by the propellant. In summary, whether or not a propellant is labelled as 'green', only depends on the GHS toxicity class, but the 'degree of greenness' of a 'green' propellant is determined by the HRI.

\section{PROPELLANT ASSESSMENT}

Storable propellants can be divided into three groups:

1. Monopropellants: Single or multiple component propellants, stored in a single propellant tank, that release energy through an exothermic decomposition reaction (e.g. hydrazine).

2. PreMixed Propellants (PMP's): Multiple component propellants consisting of an oxidizer and a fuel stored as a blend in a single propellant tank, that release energy through a decomposition and/or combustion reaction (e.g. LMP-103s, AF-M135E and Nitrous Oxide Fuel Blend's).

3. Bipropellants: Dual component propellants consisting of a separately stored oxidizer and a fuel, that release energy through a combustion_reaction (e.g. $\mathrm{MON} / \mathrm{MMH}$ ),

This section discusses the methods and results of a propellant assessment activity performed by TNO. The goal of this activity was to identify promising 'green' propellants, and to perform a propellant trade-off to select one monopropellant and one bipropellant combination for further study. Pre-mixed propellants have been evaluated as well, but they were not included in the final propellant trade-off.

\subsection{Propellant requirements}

A storable 'green' propellant should satisfy a minimum set of requirements in order to be an interesting candidate for replacing hydrazine and/or its derivatives. The requirements as used by TNO during the propellant assessment activity are shown in Table 3. These requirements are partly based on "Invitation To Tender (ITT) on the assessment of high performance green propellants", issued by the European Space Agency (ESA) [5]. Any propellant that does not satisfy this minimum set of requirements is considered unsuitable and was not included in the propellant trade-off.

Table 3 Requirements for alternative space propulsion propellants

\begin{tabular}{|l|l|}
\hline ID & Description \\
\hline Req. 1 & $\begin{array}{l}\text { Propellants shall be liquid in parts of the region defined as: } \\
\text { a. pressure levels within an enclosed department around } 1 \text { bar to } 30 \text { bar absolute } \\
\text { b. Temperature range between }-30^{\circ} \mathrm{C} \text { and }+80^{\circ} \mathrm{C}\end{array}$ \\
\hline Req. 2 & The freezing point of the propellant shall be lower than $-10^{\circ} \mathrm{C}$ \\
\hline Req. 3 & $\begin{array}{l}\text { The propellant shall not precipitate, crystallize or incur in phase separation and/or stratification in any form } \\
\text { within the pressure and temperature ranges of Req. } 1 \text {. In addition, in the event the propellant changes states } \\
\text { or precipitates due to abnormal pressure/temperature conditions, the propellant shall not change neither } \\
\text { physical/chemical nor performance properties once nominal pressure/temperature conditions are recovered. }\end{array}$ \\
\hline Req. 4 & Propellants are not registered by ECHA as concerned material and they have to be compliant to article 57 of REACH. \\
\hline Req. 5 & Propellant handling shall not need any SCAPE suits. \\
\hline
\end{tabular}




\begin{tabular}{|l|l|}
\hline ID & Description \\
\hline Req. 6 & $\begin{array}{l}\text { Propellants, used as monopropellant, shall have a specific impulse higher than the current used baseline propellant } \\
\text { hydrazine plus } 15 \text { percent ( }>258 \text { s) (based on a combustion pressure of } 10 \text { bar and a nozzle expansion ratio of 50) }\end{array}$ \\
\hline Req. 7 & $\begin{array}{l}\text { Propellants used as bipropellant shall have a specific impulse higher than } 90 \% \text { of the current baseline MMH/ } \\
\text { NTO }(>310 \text { s) (based on a combustion pressure of } 10 \text { bar and a nozzle expansion ratio of 50) }\end{array}$ \\
\hline Req. 8 & The performance of a bipropellant system shall be evaluated at the stoichiometric mixture ratio \\
\hline Req. 9 & The propellant shall be usable with at least one of the pressurant gasses listed in "ECSS-QW-70-71a". \\
\hline Req. 10 & The propellant shall have a GHS acute toxicity classification of 3 or higher \\
\hline Req. 11 & The propellant shall be insensitive to shock and vibration \\
\hline Req. 12 & The propellant shall not be pyrophoric \\
\hline Req. 13 & The propellant shall be transportable by road \\
\hline Req. 14 & The propellant shall be capable of being used in thrusters that operate in pulsed-mode \\
\hline
\end{tabular}

\subsection{Trade-off method}

Only the propellants that satisfy all requirements in Table 3 were considered as suitable candidates to replace hydrazine and its derivatives. These propellants were evaluated in the propellant trade-off, in order to select the most promising monopropellant and bipropellant for further study. In this trade-off, the propellants were assessed against a set of trade-off criteria, which are given in Table 4. The trade-off criteria are so called "Measures of Effectiveness" (MoE), which are quantities that can be used to assess how well a propellant 'performs' beyond the requirements.

Table 4 Measures of effectiveness that were used as trade-off criteria

\begin{tabular}{|c|c|c|c|}
\hline MoE & Symbol & Rationale & Method \\
\hline $\begin{array}{l}\text { Gravimetric Specific } \\
\text { Impulse }\end{array}$ & $\begin{array}{l}I_{s p} \\
{[s]}\end{array}$ & $\begin{array}{l}\text { For space craft propulsion the } I_{s p} \text { is one of the most } \\
\text { important engine parameters, the higher the better. }\end{array}$ & $\begin{array}{l}\text { CEA with chamber } \\
\text { pressure of } 10 \text { bar and } \\
\text { area expansion ratio of } 50 \\
\text { assuming frozen flow. }\end{array}$ \\
\hline $\begin{array}{l}\text { Volumetric Specific } \\
\text { Impulse }\end{array}$ & 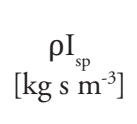 & $\begin{array}{l}\text { A high density of the propellant is desirable because } \\
\text { this results in to a smaller and lighter tank for a given } \\
\text { propellant mass. }\end{array}$ & $\begin{array}{l}\text { Density from literature } \\
\text { multiplied by } I_{s p}\end{array}$ \\
\hline $\begin{array}{l}\text { Chamber } \\
\text { Temperature }\end{array}$ & $\begin{array}{c}\mathrm{T}_{\mathrm{C}} \\
{[\mathrm{K}]}\end{array}$ & $\begin{array}{l}\text { The temperature of the gases in the engine chamber } \\
\text { introduces a strong design requirement on the thruster } \\
\text { design and thermo control. }\end{array}$ & $\begin{array}{l}\text { CEA with chamber } \\
\text { pressure of } 10 \text { bar and } \\
\text { area expansion ratio of } 50 \\
\text { assuming frozen flow. }\end{array}$ \\
\hline $\begin{array}{l}\text { Freezing } \\
\text { temperature }\end{array}$ & $\underset{\left[{ }^{\circ} \mathrm{C}\right]}{\mathrm{T}_{\mathrm{F}}}$ & $\begin{array}{c}\text { To limit the power consumption required for ensuring } \\
\text { a liquid propellant. A low freezing temperature is } \\
\text { appreciated }\end{array}$ & Literature \\
\hline $\begin{array}{c}\text { Ignition } \\
\text { characteristics }\end{array}$ & $\begin{array}{l}\text { Ign. } \\
{[-]}\end{array}$ & $\begin{array}{l}\text { A simple ignition of the propellant will simplify the } \\
\text { propulsion system architecture, reduces mass and } \\
\text { reduces the failure modes. } \\
\text { Ignitability is expressed as a score between } 0 \text { and } 10 \\
\text { (increasing number for increasing ignitability) }\end{array}$ & $\begin{array}{l}\text { Catalytic or hypergolic } \\
\text { ignition are preferred, } \\
\text { otherwise a low activation } \\
\text { energy is preferred. Data is } \\
\text { obtained from literature. }\end{array}$ \\
\hline
\end{tabular}




\begin{tabular}{|c|c|c|c|}
\hline MoE & Symbol & Rationale & Method \\
\hline Health Risk Index & $\begin{array}{c}\text { HRI } \\
{[-]}\end{array}$ & $\begin{array}{c}\text { In order to promote easy storage and handling, } \\
\text { a propellant must pose as little health risks as possible. } \\
\text { HRI is expressed as a dimensionless number, which } \\
\text { increases with increasing health risk. }\end{array}$ & $\begin{array}{c}\text { Literature values for vapor } \\
\text { pressure and } \text { LC }_{50}\end{array}$ \\
\hline Carbon fraction & C $_{\text {frac }}$ & $\begin{array}{c}\text { To avoid the formation of soot, especially in pulse } \\
\text { mode operation of the engine, the amount of carbon } \\
\text { in the propellant should be low. The carbon fraction } \\
\text { is expressed in the number of carbon atoms in the } \\
\text { molecule }\end{array}$ & $\begin{array}{c}\text { Fraction of carbon atoms in } \\
\text { the molecule }\end{array}$ \\
\hline Availability & A & $\begin{array}{c}\text { The availability of the propellant influences the } \\
\text { development and operational cost of the thruster } \\
\text { system. Availability is expressed as a score between } \\
\text { 1 and 10, with an increasing number for increasing } \\
\text { availability }\end{array}$ & $\begin{array}{c}\text { Literature and vendor } \\
\text { information }\end{array}$ \\
\hline $\begin{array}{c}\text { Uncertainty } \\
\text { of Meeting } \\
\text { Requirements }\end{array}$ & U & $\begin{array}{c}\text { Since data may be missing for some propellants, } \\
\text { a reservation for uncertainty needs to be made. } \\
\text { Uncertainty is expressed as a score from 1 to 10, with } \\
\text { an increasing number for increasing uncertainty. }\end{array}$ & $\begin{array}{c}\text { Availability of data on the } \\
\text { requirements and MoE's }\end{array}$ \\
\hline
\end{tabular}

In order to score each candidate propellant objectively against the trade-off criteria in Table 4, a 'value function' was defined for each criterion. These value functions define the relationship between the actual value of a certain trade-off parameter (for example, the actual gravimetric specific impulse of a certain propellant) and the corresponding trade-off score, which is a number between 0 and 10 . Three types of value functions were used, i,e. 'The higher the better', 'The smaller the better' and a 'Three level discrete' function. These three types of value functions are shown in Figure 1. Note that for each trade-off criterion, the quantity on the $\mathrm{x}$-axis will is different. Table 5 shows an overview of each trade-off criterion with the appropriate value function, and the strategy that was followed to define the appropriate range on the $\mathrm{x}$-axis.
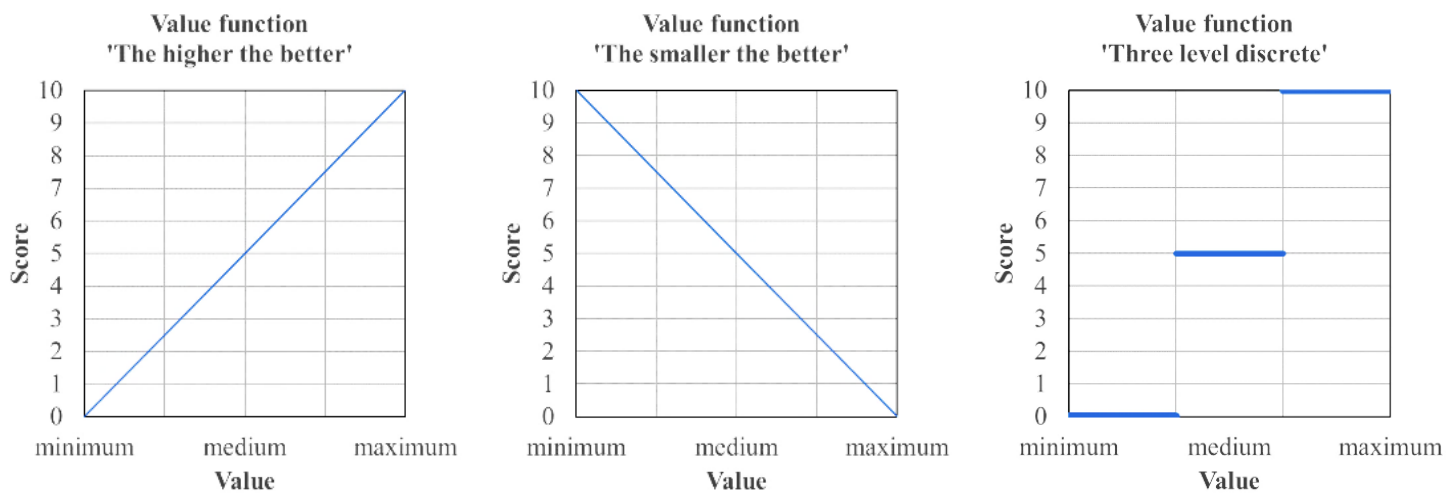

Figure 1 Graphical representation of the value functions 
Table 5 Value function characteristics of each measurement of effectiveness

\begin{tabular}{|c|c|c|c|c|}
\hline MoE & Value function & minimum & medium & maximum \\
\hline $\begin{array}{l}\text { Gravimetric } \\
\text { Specific Impulse }\end{array}$ & $\begin{array}{l}\text { The higher the } \\
\text { better }\end{array}$ & Minimum required & $(\min .+\max ) / 2$. & $\begin{array}{c}\text { Highest of evaluated } \\
\text { propellants }\end{array}$ \\
\hline $\begin{array}{l}\text { Volumetric } \\
\text { Specific Impulse }\end{array}$ & $\begin{array}{c}\text { The higher the } \\
\text { better }\end{array}$ & $\begin{array}{c}\text { Lowest of evaluated } \\
\text { propellants }\end{array}$ & $(\min .+\max ) / 2$. & $\begin{array}{l}\text { Highest of evaluated } \\
\text { propellants }\end{array}$ \\
\hline $\begin{array}{l}\text { Combustion } \\
\text { Temperature }\end{array}$ & $\begin{array}{l}\text { The smaller the } \\
\text { better }\end{array}$ & $\begin{array}{l}\text { Highest chamber } \\
\text { temperature of the } \\
\text { evaluated propellants }\end{array}$ & $(\min .+\max ) / 2$. & $\begin{array}{l}\text { The chamber temperature } \\
\text { of current state of the art } \\
\text { propellant. }\end{array}$ \\
\hline $\begin{array}{l}\text { Practical } \\
\text { temperature } \\
\text { range/melting } \\
\text { temperature }\end{array}$ & $\begin{array}{l}\text { The smaller the } \\
\text { better }\end{array}$ & $\begin{array}{c}\text { Highest freezing } \\
\text { temperature of } \\
\text { evaluated propellants }\end{array}$ & $(\min .+\max ) / 2$. & $\begin{array}{l}\text { Lowest freezing } \\
\text { temperature of evaluated } \\
\text { propellants }\end{array}$ \\
\hline $\begin{array}{l}\text { Ignition } \\
\text { characteristics }\end{array}$ & Three level discrete & $\begin{array}{l}\text { No catalytic initiation } \\
\text { is possible (hypergolic } \\
\text { initiation for } \\
\text { bipropellants) }\end{array}$ & $\begin{array}{l}\text { Catalytic initiation } \\
\text { is demonstrated } \\
\text { but with problems } \\
\text { (hypergolic initiation for } \\
\text { bipropellants) }\end{array}$ & $\begin{array}{l}\text { Catalytic initiation } \\
\text { is demonstrated } \\
\text { without problems } \\
\text { (hypergolic initiation for } \\
\text { bipropellants) }\end{array}$ \\
\hline $\begin{array}{l}\text { Health Risk } \\
\text { Index }\end{array}$ & $\begin{array}{l}\text { The smaller the } \\
\text { better }\end{array}$ & $\begin{array}{l}\text { Highest of evaluated } \\
\text { propellants }\end{array}$ & $(\min .+\max ) / 2$. & $\begin{array}{c}\text { Lowest of evaluated } \\
\text { propellants }\end{array}$ \\
\hline Carbon fraction & $\begin{array}{c}\text { The smaller the } \\
\text { better }\end{array}$ & Highest carbon fraction & $(\min .+\max ) / 2$. & Lowest carbon fraction \\
\hline Availability & Three level discrete & $\begin{array}{l}\text { Specialized synthesized } \\
\text { compound with less } \\
\text { than } 5 \text { identified } \\
\text { vendors }\end{array}$ & $\begin{array}{l}\text { Synthesized compound } \\
\text { with more than } 5 \\
\text { identified vendors }\end{array}$ & $\begin{array}{l}\text { Common compound } \\
\text { with general use } \\
\text { in industry, hence } \\
\text { numerous vendors }\end{array}$ \\
\hline $\begin{array}{l}\text { Uncertainty } \\
\text { of Meeting } \\
\text { Requirements }\end{array}$ & $\begin{array}{c}\text { The smaller the } \\
\text { better }\end{array}$ & 0 & $(\min .+\max ) / 2$. & $\begin{array}{c}\text { Number of requirements } \\
\text { for which compliance is } \\
\text { uncertain }\end{array}$ \\
\hline
\end{tabular}

In addition to a score, each trade-off criterion was assigned a relative weight factor (number between 0 and 1). As the assignment of weight factors can be somewhat subjective, the propellant tradeoffs have been performed with three different sets of weight factors, each set reflecting different priorities. The ranking scenarios that are reflected by the three sets of weight factors are:

1. Balanced scenario: The trade-off criteria are of more of less equal importance and are assigned similar weight factors. Propellants that score well 'across the board' will end up high in the trade-off when this set of weight factors is applied.

2. Maximum performance scenario: The trade-off criteria related to performance are considered more important than the other criteria. Hence, these criteria are assigned higher relative weight factors than the other criteria. Propellants that score especially well on performance will end up high in the trade-off. when this set of weight factors is applied.

3. Conservative scenario: The uncertainty of whether or not a propellant can satisfy all the requirements in Table 3 is considered the most important trade-off criterion. Propellants that are 
associated with the smallest number of uncertainties will end up high in the trade-off when this set of weight factors is used.

An overview of the weight factors of the three scenarios is given in Table 6 .

Table 6 Relative weight factors for the three ranking scenarios

\begin{tabular}{|l|c|c|c|c|c|c|c|c|c|}
\hline Scenario & $\mathbf{T}_{\mathbf{F}}$ & $\mathbf{I}_{\mathrm{sp}}$ & $\mathbf{I}_{\mathrm{sp}}$ & $\mathbf{T}_{\mathbf{C}}$ & $\mathbf{H R I}$ & $\mathbf{C}_{\text {frac }}$ & $\mathbf{A .}$ & $\mathbf{I g n .}$ & $\mathbf{U .}$ \\
\hline Balanced & 0.10 & 0.15 & 0.15 & 0.10 & 0.10 & 0.10 & 0.05 & 0.15 & 0.10 \\
\hline $\begin{array}{l}\text { Maximum } \\
\text { performance }\end{array}$ & 0.05 & 0.25 & 0.20 & 0.05 & 0.05 & 0.05 & 0.05 & 0.25 & 0.05 \\
\hline Conservative & 0.05 & 0.10 & 0.10 & 0.05 & 0.30 & 0.10 & 0.05 & 0.10 & 0.15 \\
\hline
\end{tabular}

\subsection{Propellant identification and evaluation}

This paragraph gives an overview of all fuels and oxidizers that have been considered during the propellant assessment activity and the subset of propellants that have been included in the propellant trade-off. The reported specific impulses of the different propellants have been calculated with the NASA CEA thermochemistry code [6][7], assuming a chamber pressure of 10 bar, a nozzle area ratio of 50 and an initial propellant temperature of $293.15 \mathrm{~K}$.

\section{Hydrocarbons and alcohols}

Hydrocarbons and alcohols have a negative oxygen balance therefore have been considered as potential 'fuels' for a bipropellant system. Alcohols are organic compounds in which a hydroxyl group $(\mathrm{OH})$ is bound to a saturated carbon atom. From a performance point of view, it is favourable to have as little hydroxyl groups as possible. In general, alcohols with more than one $\mathrm{OH}$ group have insufficient specific impulse to satisfy requirement 7 in Table 3. Therefore, only alcohols with a single $\mathrm{OH}$ group were included in the trade-off.

Hydrocarbons are organic compounds that consists entirely of carbon and hydrogen. Three classes of 'simple' hydrocarbons can be identified, i.e. alkanes, alkenes and alkynes.

1. Alkanes are saturated hydrocarbons. The simplest alkane, methane, is gaseous at pressures between 1 and 30 bar and temperatures between $-30^{\circ} \mathrm{C}$ and $+80^{\circ} \mathrm{C}$ and therefore does not satisfy requirement 1 . Hence, methane is not included in the trade-off.

2. Alkenes are unsaturated hydrocarbons that contain at least one double carbon-carbon bond. Due to energy stored in the double carbon bond, alkene compounds typically have higher propulsive performance than their alkane equivalent. At the same time, their sensitivity is often also higher. Alkenes with more than sixteen carbon atoms in their molecule are solids, and are therefore excluded from the trade-off on the basis of violating requirement 1 .

3. Alkyne compounds are unsaturated hydrocarbons containing at least one triple carbon-carbon bond. This triple bond contains even more energy than the double bond found in alkene compounds, yielding higher propulsive potential. At the same time this triple bond increases their sensitivity to shock and vibration, making propellant storage and handling problematic. Ethyne is known to be highly unstable and is therefore not included in the trade of due to the violation of 
requirement 11 . For the other alkynes, both the stability and the toxicity classification are uncertain. Because these propellants could not be rejected beforehand, the other alkynes are included in the propellant trade-off.

Furthermore, requirement 14 specifies that the propellant shall be capable of being used in thrusters that operate in pulsed mode. For alcohols and hydrocarbon fuels with large chain lengths it will be difficult to achieve complete combustion during short pulses, which increases the risk of soot formation. This may affect the service life of the engine, but may also have a negative impact on any (optical) instruments on the platform. To limit the susceptibility for soot formation, only hydrocarbons and alcohols with a maximum of 5 carbon atoms are included in the trade-off. It has been reported that alkanes, alkenes and acetylene (ethyne) can be decomposed over a catalyst [8]. In spite of this, these hydrocarbons are not considered as monopropellant because of the formation of soot during decomposition which violates requirement 14 .

\section{Oxides of nitrogen}

Nitrogen forms many binary compounds with oxygen. This study is limited to mono and dinitrogen oxides being $\mathrm{NO}, \mathrm{NO}_{2}, \mathrm{~N}_{2} \mathrm{O}, \mathrm{N}_{2} \mathrm{O}_{3}, \mathrm{~N}_{2} \mathrm{O}_{4}$ and $\mathrm{N}_{2} \mathrm{O}_{5}$. These compounds have been evaluated as potential oxidizers for a bipropellant system. Nitric oxide (NO) is gaseous in the pressure-temperature envelope specified in requirement 1 , and is therefore not included in the trade-off. Nitrogen dioxide $\left(\mathrm{NO}_{2}\right)$ and nitrogen tetroxide $\left(\mathrm{N}_{2} \mathrm{O}_{4}\right)$ form an equilibrium mixture. These propellants are highly toxic (GHS acute toxicity class 1) and are not included in the trade-off due to violation of requirement 10. The same is true for dinitrogen trioxide $\left(\mathrm{N}_{2} \mathrm{O}_{3}\right)$, which falls in GHS class 1. Dinitrogen pentoxide $\mathrm{N}_{2} \mathrm{O}_{5}$ has a melting point of $41^{\circ} \mathrm{C}$ and is considered a solid. Therefore, $\mathrm{N}_{2} \mathrm{O}_{5}$ is rejected as a possible propellant candidate due to violation of requirement 1 . The only propellant in this group that could be a potential interesting 'green' propellant is nitrous oxide $\left(\mathrm{N}_{2} \mathrm{O}\right)$. This propellant is both relatively nontoxic (GHS class 5) and is liquid in part of the temperature-pressure envelope specified by requirement 1 . Therefore, nitrous oxide has been included in the trade-off.

\section{Hydrogen peroxide}

Hydrogen peroxide $\left(\mathrm{H}_{2} \mathrm{O}_{2}\right)$ is a well-known monopropellant as well as an oxidizer for a bipropellant combinations. Hydrogen peroxide is miscible with water, liquid at atmospheric pressure and room temperature, and relatively non-toxic. Based on its $\mathrm{LC}_{50}$ value, hydrogen peroxide is categorised as category 3 in the GHS ATC system. Hydrogen peroxide can be procured in concentrations up to $98 \%$ (in water).

As a monopropellant, hydrogen peroxide decomposes into oxygen $\left(\mathrm{O}_{2}\right)$ and water $\left(\mathrm{H}_{2} \mathrm{O}\right)$, at a decomposition temperature around $1000 \mathrm{~K}$ (for the higher concentrations). However, the specific impulse of hydrogen peroxide is only 186s at a chamber pressure of 10 bar and a nozzle area ratio of 50 . Therefore, hydrogen peroxide as a monopropellant is not included in the trade-off due to its noncompliance with requirement 6 . As an oxidizer in a bipropellant system, hydrogen peroxide can reach a specific impulse of $>310 \mathrm{~s}$, depending on the fuel that is used. Therefore, this propellant is included in the trade-off as a bipropellant candidate. 


\section{Halogen based oxidizers}

Halogen compounds have a strong oxidizing potential. Within the halogen group, only Fluor and Chlorine have a sufficiently low molecular weight and high density to be interesting propellants. However, all of the halogen and interhalogen oxidizers fall in GHS acute toxicity class 1 or 2, thereby violating requirement 10 in Table 3 . As such, they are excluded from the propellant trade-off.

\section{Dissolved energetic salts}

Energetic salts, like Hydrazinium NitroFormate (HNF), HydroxylAmmonium Nitrate (HAN) and Ammonium DiNitramide (ADN) are solids with a strong oxygen balance. They can be dissolved in water to form a liquid monopropellant or a liquid oxidizer in a bipropellant system. The performance of these dissolved salts depends on their solubility in water. In case of ADN, 357g can be dissolved in $100 \mathrm{~g}$ of water [9], forming a mixture with $78 \mathrm{wt} \% \mathrm{ADN}$. Water lowers the oxygen balance of the oxidizer and reduces the energy that can be released per gram of propellant. The maximum specific impulse that can be achieved with this propellant (i.e. a mixture of $78 \mathrm{wt} \% \mathrm{ADN}$ in water) is $192 \mathrm{~s}$ in case it is used as a monopropellant, and 268s in case it is used as an oxidizer in a bipropellant system (in combination with ethanol). For HNF and HAN in water, similar performances are obtained. As these values are well below requirement 6 and 7, energetic salts dissolved in water are excluded from the trade-off.

The above mentioned energetic salts can also be dissolved in a fuel (e.g. methanol or ethanol) to form a pre-mixed propellant. As a PMP releases its energy (partly) through a combustion reaction, the specific impulse of these propellants are generally much higher than of most monopropellants, although this high performance comes with a temperature penalty. For instance, LMP-103 (an ADN based PMP developed by ECAPS), has a reported specific impulse of 252s [9]. However, as PMPs are considered a separate class of propellants besides monopropellants and bipropellants, the PMPs have not been included in the propellant trade-off. Nevertheless, it is recognized that these propellants have great potential.

\section{Nitro compounds}

Nitro compounds are organic substances with one or more nitro groups $\left(\mathrm{NO}_{2}\right)$. There are several nitro compounds that are liquid in part of the temperature-pressure envelope specified by requirement 1 , including nitromethane, dinitromethane, trinitromethane (nitroform) and tetranitromethane. These propellants can either be used as monopropelants or as fuels in bipropellant systems. From this group, tetranitromethane has a very low $\mathrm{LC}_{50}$ value $(18 \mathrm{ppm})$ and fall in GHS acute toxicity class 1. It is therefore not included in the propellant trade-off. Dinitromethane is reported as unstable at room temperature [10] and the transportation of dinitromethane is prohibited by the US Department of Transportation[11]. Hence, dinitromethane is excluded from the trade-off due to its violation of requirement 11 . The only promising candidate within this group of nitro-compounds is (mono)nitromethane. This propellant is relatively nontoxic (estimated GHS acute toxicity class 4), and when used as a monopropellant, has an specific impulse of 289s which satisfies requirement 6 . When used as a fuel in a bipropellant system, nitromethane has a specific impulse of 326 s (in combination with hydrogen peroxide) and therefore satisfies requirement 7 . Therefore, nitromethane is included in the propellant trade-off. 


\section{Boron, Lithium and Beryllium Based Propellants}

In order to maximize the performance of the propellant, the molar mass of the products must be minimized. As such, propellants based on lithium, Beryllium and Boron seem attractive candidates. Pure lithium has been used as a propellant in combination with liquid fluorine and liquid hydrogen in a "tribrid" system. Due to its high toxicity, its melting point of $180.5^{\circ} \mathrm{C}$, and its reactivity with air and water disqualifies lithium as storable liquid propellant (violation of requirements 1 and 12). No other suitable lithium based compounds have been identified.

Beryllium based fuels are mainly suited for solid rocket propellant. Only Beryllium hydride (BeH2) was identified as a potential fuel additive. Beryllium hydride is a solid at room temperature and will decompose rather than melt. Furthermore, being a hydride, it will react violently with water and therefore cannot be dissolved in water to obtain a liquid fuel. Furthermore, beryllium hydrides are highly toxic and hence unsuited for use in a low toxicity propellant. No other beryllium based compounds have been identified that could be suitable as fuel component.

Boron based fuels were the object of a significant R\&D effort in the 50s, 60s and 70s in the USA, USSR and Europe. Of all the low mass elements, boron has a combination of high energy, low molecular mass and a relatively wide availability. From a fuel perspective, boranes (boron hydrides, e.g. boron-hydrogen compounds) have the most potential due to their high specific energy. As such, a number of borane fuels, most notably diborane $\left(\mathrm{B}_{2} \mathrm{H}_{6}\right)$ and pentaborane $\left(\mathrm{B}_{5} \mathrm{H}_{9}\right)$ have been studied for use both as high energy jet fuel and as rocket propellant.

Despite the significant effort, borane based fuels have not found any application. All borane fuels have numerous problems. Firstly, the combustion products are highly toxic. Secondly, borane fuels form solid particles $\left(\mathrm{B}_{2} \mathrm{O}_{3}\right)$ when combusted, significantly lowering the specific impulse of the propellant (and potentially damaging the thruster). As such, borane based fuels are mainly suitable to use in combination with halogen oxidizers. As mentioned before however, most identified halogen oxidizers exhibit the same high acute toxicity risks and are hence not suitable as a low toxicity propellant. Considering the significant (unsuccessful) R\&D efforts that was performed around the globe to realize the performance potential of borane fuels, and because of the high acute toxicity, boron based propellants are not studied in further detail in this study.

\section{Summary}

From all potential propellants that were discussed in this paragraph, many could already be excluded from the trade-off beforehand, because they are not compliant with one or more requirements in Table 3. The other potential propellants are either fully compliant with the requirements or compliance with one or more requirements is uncertain at this point, due to a lack of available data. These propellants have all been included in the propellant trade-off, and are summarized in Table 7 . The table shows the propellant, whether it could be used as a monopropellant $(\mathrm{M})$, a fuel $(\mathrm{F})$ in a bipropellant system or an oxidizer $(\mathrm{O})$ in a bipropellant system, and whether it is compliant with the requirements in Table 3 (C=compliant, $\mathrm{CU}=$ compliance uncertain $)$. 
Table 7 Requirements compliancy overview of all propellants that are included in the trade-off. "C" = Compliant, "CU" = Compliance Uncertain.

\begin{tabular}{|c|c|c|c|c|c|c|c|c|c|c|c|c|c|c|c|}
\hline \multirow{2}{*}{ Propellant } & \multirow{2}{*}{$\begin{array}{c}\text { Type of } \\
\text { propellant }\end{array}$} & \multicolumn{14}{|c|}{ Requirement from Table 3} \\
\hline & & 1 & 2 & 3 & 4 & 5 & 6 & 7 & 8 & 9 & 10 & 11 & 12 & 13 & 14 \\
\hline Methanol & $\mathrm{F}$ & $\mathrm{C}$ & $\mathrm{C}$ & $\mathrm{C}$ & $\mathrm{C}$ & $\mathrm{C}$ & $\mathrm{C}$ & $\mathrm{C}$ & $\mathrm{C}$ & $\mathrm{C}$ & $\mathrm{C}$ & $\mathrm{C}$ & $\mathrm{C}$ & $\mathrm{C}$ & $\mathrm{C}$ \\
\hline Ethanol & F & $\mathrm{C}$ & $\mathrm{C}$ & $\mathrm{C}$ & $\mathrm{C}$ & $\mathrm{C}$ & $\mathrm{C}$ & $\mathrm{C}$ & $\mathrm{C}$ & $\mathrm{C}$ & $\mathrm{C}$ & $\mathrm{C}$ & $\mathrm{C}$ & $\mathrm{C}$ & $\mathrm{C}$ \\
\hline Propanol & $\mathrm{F}$ & $\mathrm{C}$ & $\mathrm{C}$ & $\mathrm{C}$ & $\mathrm{C}$ & $\mathrm{C}$ & $\mathrm{C}$ & $\mathrm{C}$ & $\mathrm{C}$ & $\mathrm{C}$ & $\mathrm{C}$ & $\mathrm{C}$ & $\mathrm{C}$ & $\mathrm{C}$ & $\mathrm{C}$ \\
\hline Butanol & F & $\mathrm{C}$ & $\mathrm{C}$ & $\mathrm{C}$ & $\mathrm{C}$ & $\mathrm{C}$ & $\mathrm{C}$ & $\mathrm{C}$ & $\mathrm{C}$ & $\mathrm{C}$ & $\mathrm{C}$ & $\mathrm{C}$ & $\mathrm{C}$ & $\mathrm{C}$ & $\mathrm{C}$ \\
\hline Pentanol & F & $\mathrm{C}$ & $\mathrm{C}$ & $\mathrm{C}$ & $\mathrm{C}$ & $\mathrm{C}$ & $\mathrm{C}$ & $\mathrm{C}$ & $\mathrm{C}$ & $\mathrm{C}$ & $\mathrm{C}$ & $\mathrm{C}$ & $\mathrm{C}$ & $\mathrm{C}$ & $\mathrm{C}$ \\
\hline Ethane & F & $\mathrm{C}$ & $\mathrm{C}$ & $\mathrm{C}$ & $\mathrm{C}$ & $\mathrm{C}$ & $\mathrm{C}$ & $\mathrm{C}$ & $\mathrm{C}$ & $\mathrm{C}$ & $\mathrm{C}$ & $\mathrm{C}$ & $\mathrm{C}$ & $\mathrm{C}$ & $\mathrm{C}$ \\
\hline Propane & F & $\mathrm{C}$ & $\mathrm{C}$ & $\mathrm{C}$ & $\mathrm{C}$ & $\mathrm{C}$ & $\mathrm{C}$ & $\mathrm{C}$ & $\mathrm{C}$ & $\mathrm{C}$ & $\mathrm{C}$ & $\mathrm{C}$ & $\mathrm{C}$ & $\mathrm{C}$ & $\mathrm{C}$ \\
\hline Butane & $\mathrm{F}$ & $\mathrm{C}$ & $\mathrm{C}$ & $\mathrm{C}$ & C & $\mathrm{C}$ & C & $\mathrm{C}$ & $\mathrm{C}$ & $\mathrm{C}$ & C & $\mathrm{C}$ & $\mathrm{C}$ & $\mathrm{C}$ & $\mathrm{C}$ \\
\hline Pentane & $\mathrm{F}$ & $\mathrm{C}$ & $\mathrm{C}$ & $\mathrm{C}$ & $\mathrm{C}$ & $\mathrm{C}$ & $\mathrm{C}$ & $\mathrm{C}$ & $\mathrm{C}$ & $\mathrm{C}$ & $\mathrm{C}$ & $\mathrm{C}$ & $\mathrm{C}$ & $\mathrm{C}$ & $\mathrm{C}$ \\
\hline Ethene & $\mathrm{F}$ & $\mathrm{C}$ & $\mathrm{C}$ & $\mathrm{C}$ & C & $\mathrm{C}$ & $\mathrm{C}$ & $\mathrm{C}$ & $\mathrm{C}$ & $\mathrm{C}$ & $\mathrm{C}$ & $\mathrm{C}$ & $\mathrm{C}$ & $\mathrm{C}$ & $\mathrm{C}$ \\
\hline Propene & F & $\mathrm{C}$ & $\mathrm{C}$ & $\mathrm{C}$ & $\mathrm{C}$ & $\mathrm{C}$ & $\mathrm{C}$ & $\mathrm{C}$ & $\mathrm{C}$ & $\mathrm{C}$ & $\mathrm{C}$ & $\mathrm{C}$ & $\mathrm{C}$ & $\mathrm{C}$ & $\mathrm{C}$ \\
\hline Butene & $\mathrm{F}$ & $\mathrm{C}$ & $\mathrm{C}$ & $\mathrm{C}$ & $\mathrm{C}$ & $\mathrm{C}$ & $\mathrm{C}$ & $\mathrm{C}$ & $\mathrm{C}$ & $\mathrm{C}$ & $\mathrm{C}$ & $\mathrm{C}$ & $\mathrm{C}$ & $\mathrm{C}$ & C \\
\hline Pentene & $\mathrm{F}$ & $\mathrm{C}$ & $\mathrm{C}$ & $\mathrm{C}$ & $\mathrm{C}$ & $\mathrm{C}$ & $\mathrm{C}$ & $\mathrm{C}$ & $\mathrm{C}$ & $\mathrm{C}$ & $\mathrm{C}$ & $\mathrm{C}$ & $\mathrm{C}$ & $\mathrm{C}$ & $\mathrm{C}$ \\
\hline Propyne & $\mathrm{F}$ & $\mathrm{C}$ & $\mathrm{C}$ & $\mathrm{C}$ & $\mathrm{C}$ & $\mathrm{C}$ & $\mathrm{C}$ & $\mathrm{C}$ & $\mathrm{C}$ & $\mathrm{C}$ & $\mathrm{CU}$ & $\mathrm{CU}$ & $\mathrm{C}$ & $\mathrm{CU}$ & $\mathrm{C}$ \\
\hline Butyne & $\mathrm{F}$ & $\mathrm{C}$ & $\mathrm{CU}$ & $\mathrm{C}$ & $\mathrm{C}$ & $\mathrm{C}$ & $\mathrm{C}$ & $\mathrm{C}$ & $\mathrm{C}$ & $\mathrm{C}$ & $\mathrm{CU}$ & $\mathrm{CU}$ & $\mathrm{C}$ & $\mathrm{CU}$ & $\mathrm{C}$ \\
\hline Pentyne & F & $\mathrm{C}$ & $\mathrm{C}$ & $\mathrm{C}$ & $\mathrm{C}$ & $\mathrm{C}$ & $\mathrm{C}$ & $\mathrm{C}$ & $\mathrm{C}$ & $\mathrm{C}$ & $\mathrm{CU}$ & $\mathrm{CU}$ & $\mathrm{C}$ & $\mathrm{CU}$ & $\mathrm{C}$ \\
\hline Nitromethane & $\mathrm{M}, \mathrm{F}$ & $\mathrm{C}$ & $\mathrm{C}$ & $\mathrm{C}$ & $\mathrm{C}$ & C & $\mathrm{C}$ & C & $\mathrm{C}$ & C & $\mathrm{C}$ & $\mathrm{C}$ & C & $\mathrm{C}$ & C \\
\hline $\begin{array}{l}\text { Hydrogen } \\
\text { peroxide }\end{array}$ & $\mathrm{O}$ & $\mathrm{C}$ & $\mathrm{C}$ & $\mathrm{C}$ & $\mathrm{C}$ & $\mathrm{C}$ & $\mathrm{C}$ & $\mathrm{C}$ & $\mathrm{C}$ & $\mathrm{C}$ & $\mathrm{C}$ & $\mathrm{C}$ & $\mathrm{C}$ & $\mathrm{C}$ & C \\
\hline Nitrous oxide & $\mathrm{O}$ & $\mathrm{C}$ & $\mathrm{C}$ & $\mathrm{C}$ & $\mathrm{C}$ & $\mathrm{C}$ & $\mathrm{C}$ & $\mathrm{C}$ & $\mathrm{C}$ & $\mathrm{C}$ & $\mathrm{C}$ & $\mathrm{C}$ & $\mathrm{C}$ & $\mathrm{C}$ & $\mathrm{C}$ \\
\hline
\end{tabular}

\subsection{Monopropellant trade off results}

As was discussed in paragraph 3.3, only one real monopropellant was found that is compliant with the propellant requirements in Table 3, which is (mono)nitromethane. Hence, the monopropellant trade-off reduces to an evaluation on how well nitromethane scores on the MoEs that were defined in Table 4. The MoE's for nitromethane are given in Table 8.

Table 8 Measures of Effectiveness for nitromethane

\begin{tabular}{|l|c|c|c|c|c|c|c|c|c|}
\hline Monopropellant & $\begin{array}{c}\mathbf{T}_{\mathbf{F}} \\
{ }^{\circ} \mathrm{C}\end{array}$ & $\begin{array}{c}\mathbf{I}_{\text {sp }} \\
\mathbf{s}\end{array}$ & $\begin{array}{c}\rho_{\text {sp }} \\
\mathbf{k g . s . m}^{-3}\end{array}$ & $\begin{array}{c}\mathbf{T}_{\mathbf{C}} \\
\mathbf{K}\end{array}$ & $\begin{array}{c}\text { HRI } \\
-\end{array}$ & $\begin{array}{c}\mathbf{C}_{\text {frac }} \\
-\end{array}$ & $\begin{array}{c}\text { A. } \\
-\end{array}$ & $\begin{array}{c}\text { Ign. } \\
-\end{array}$ & $\begin{array}{c}\mathbf{U} \\
-\end{array}$ \\
\hline Numerical value of MoE & -28.4 & 289 & 329 & 2449 & 2.7 & 0.14 & 10 & 5 & 0 \\
\hline
\end{tabular}

Nitromethane scores good on performance but unfortunately this results in a penalty on chamber temperature which is high. The highe chamber temperature requires design solutions on engine level that are not required for the current hydrazine engines. A possible design solution maybe the implementation of regenerative cooling. 
In literature the initiation of nitromethane decomposition is mentioned to be difficult at the pressure levels and a characteristic length that are common for thrusters[12]. This literature however is old and the details of the tests performed are limited. This literature also suggests the use of additives to improve the decomposition characteristics of nitromethane.

It is concluded that only a single monopropellant, nitromethane, was found that outperforms hydrazine and is considered 'green'. In an engine application design solutions have to be included to coop with the high chamber temperature and possible initiation difficulties.

\subsection{Bipropellant trade off}

This paragraph discusses the results of the trade-off over bipropellant combinations.

As oxidizer nitrous oxide and hydrogen peroxide were identified as possible oxidizer for a green propulsion system. With ethanol as reference fuel the measures of effectiveness are determined (Table 9).

Table 9 Measures of effectiveness for oxidizers with ethanol as fuel at stoichiometric mixture ratio

\begin{tabular}{|c|c|c|c|c|c|c|c|c|c|c|c|c|}
\hline & \multicolumn{3}{|c|}{ Properties } & \multicolumn{9}{|c|}{ Measures of effectiveness } \\
\hline Oxidizer & $\begin{array}{l}\mathrm{LC}_{50} \\
\mathrm{ppm}\end{array}$ & $\begin{array}{c}\rho_{\text {oxid }} \\
\mathbf{g} / \mathbf{c m}^{3}\end{array}$ & $\begin{array}{l}P_{\text {vap }} \\
\text { kPa }\end{array}$ & $\begin{array}{l}\mathrm{T}_{\mathrm{F}} \\
{ }^{\circ} \mathrm{C}\end{array}$ & $\begin{array}{c}I_{s p} \\
s\end{array}$ & $\begin{array}{c}\rho I_{s p} \\
\text { kg.s.m }{ }^{-3}\end{array}$ & $\begin{array}{l}\mathbf{T}_{\mathrm{C}} \\
\mathbf{K}\end{array}$ & $\begin{array}{c}\text { HRI } \\
-\end{array}$ & $\begin{array}{c}\mathrm{C}_{\text {frac }} \\
-\end{array}$ & $\begin{array}{l}\text { A. } \\
-\end{array}$ & $\begin{array}{c}\text { Ign. } \\
-\end{array}$ & $\begin{array}{l}\text { U. } \\
-\end{array}$ \\
\hline $\mathrm{H}_{2} \mathrm{O}_{2}$ & 1418 & 1.45 & 0.66 & -0.43 & 325 & 431.4 & 2752 & 0.7 & 0 & 5 & 10 & 0 \\
\hline $\mathrm{N}_{2} \mathrm{O}$ & 36514 & 0.77 & 5150 & -90.86 & 306 & 236.5 & 3025 & 29.5 & 0 & 10 & 5 & 1 \\
\hline
\end{tabular}

The specific impulse of nitrous oxide oxidizer and ethanol fuel is below the value specified by requirement 7 (310 s). This may be because of the use of ethanol as reference fuel. Nitrous oxide is not discarded in the trade-off but an additional uncertainty is added. In Table 10 the results of the trade-off are summarized.

Table 10 Oxidizer trade-off results for all three scenario's

\begin{tabular}{|l|l|c|c|c|c|c|c|c|c|c|c|}
\hline Oxidizer & & $\begin{array}{c}\text { Score } \\
(\mathbf{\%})\end{array}$ & $\begin{array}{c}\mathbf{T}_{\mathbf{F}} \\
{ }^{\circ} \mathrm{C}\end{array}$ & $\begin{array}{c}\mathbf{I}_{\mathbf{s p}} \\
\mathbf{s}\end{array}$ & $\begin{array}{c}\mathbf{\rho}_{\mathbf{s p}} \\
\mathbf{k g . s .} \mathbf{m}^{-3}\end{array}$ & $\begin{array}{c}\mathbf{T}_{\mathbf{C}} \\
\mathbf{K}\end{array}$ & $\begin{array}{c}\text { HRI } \\
-\end{array}$ & $\begin{array}{c}\mathbf{C}_{\text {frac }} \\
-\end{array}$ & $\begin{array}{c}\mathbf{A} . \\
-\end{array}$ & $\begin{array}{c}\text { Ign. } \\
-\end{array}$ & $\begin{array}{c}\mathbf{U} . \\
-\end{array}$ \\
\hline $\mathrm{H}_{2} \mathrm{O}_{2}$ & Trade-off score & & 0.0 & 10.0 & 10.0 & 10.0 & 10.0 & 10.0 & 5.0 & 10.0 & 10.0 \\
\hline & Score x Weight factor 1 & $\mathbf{7 9}$ & 0.0 & 1.5 & 1.5 & 1.0 & 1.0 & 1.0 & 0.3 & 1.5 & 1.0 \\
\hline & Score x Weight factor 2 & $\mathbf{9 3}$ & 0.0 & 2.5 & 2.5 & 0.5 & 0.5 & 0.5 & 0.3 & 2.0 & 0.5 \\
\hline & Score x Weight factor 3 & $\mathbf{8 8}$ & 0.0 & 1.0 & 1.0 & 0.5 & 2.0 & 0.5 & 0.3 & 2.0 & 1.5 \\
\hline $\mathrm{N}_{2} \mathrm{O}$ & Trade-off score & & 10.0 & 0.0 & 0.0 & 0.0 & 0.0 & 10.0 & 10.0 & 5.0 & 9.2 \\
\hline & Score x Weight factor 1 & $\mathbf{3 3}$ & 1.0 & 0.0 & 0.0 & 0.0 & 0.0 & 1.0 & 0.5 & 0.8 & 0.9 \\
\hline & Score x Weight factor 2 & $\mathbf{3 0}$ & 0.5 & 0.0 & 0.0 & 0.0 & 0.0 & 0.5 & 0.5 & 1.0 & 0.5 \\
\hline & Score x Weight factor 3 & $\mathbf{3 9}$ & 0.5 & 0.0 & 0.0 & 0.0 & 0.0 & 0.5 & 0.5 & 1.0 & 1.4 \\
\hline
\end{tabular}

For each of the evaluated scenario's, hydrogen peroxide outperforms nitrogen dioxide for almost every measure of effectiveness. Hydrogen peroxide is selected as oxidizer for this study.

In Table 11 the measures of effectiveness are given of the alcohols with a carbon number up to 5 . The performance as specific impulse and chamber temperature are determined with hydrogen peroxide as oxidizer at a stoichiometric mixture ratio. 
Table 11 Measures of effectiveness for alcohols as fuel and hydrogen peroxide as oxidizer at stoichiometric mixture ratio

\begin{tabular}{|l|c|c|c|c|c|c|c|c|c|c|c|c|}
\cline { 2 - 14 } \multicolumn{1}{c|}{} & \multicolumn{4}{c|}{ Properties } & \multicolumn{10}{c|}{ Measures of effectiveness } \\
\hline Fuel & $\begin{array}{c}\mathbf{L C}_{\mathbf{5 0}} \\
\mathbf{p p m}\end{array}$ & $\begin{array}{c}\rho_{\text {fuel }} \\
\mathbf{g} / \mathbf{c m}^{\mathbf{3}}\end{array}$ & $\begin{array}{c}\mathbf{P}_{\text {vap }} \\
\mathbf{k P a}\end{array}$ & $\begin{array}{c}\mathbf{T}_{\mathbf{F}} \\
{ }^{\circ} \mathbf{C}\end{array}$ & $\begin{array}{c}\mathbf{I}_{\text {sp }} \\
\mathbf{s}\end{array}$ & $\begin{array}{c}\rho \mathbf{I}_{\text {sp }} \\
\mathbf{k g . s . m} \text {-3 }\end{array}$ & $\begin{array}{c}\mathbf{T}_{\mathbf{C}} \\
\mathbf{K}\end{array}$ & $\begin{array}{c}\mathbf{H R I} \\
-\end{array}$ & $\begin{array}{c}\mathbf{C}_{\text {frac }} \\
-\end{array}$ & $\begin{array}{c}\mathbf{A} . \\
-\end{array}$ & $\begin{array}{c}\text { Ign. } \\
-\end{array}$ & $\begin{array}{c}\text { U. } \\
-\end{array}$ \\
\hline Methanol & 64000 & 0.79 & 12.3 & -97.8 & 320 & 413.6 & 2688 & 0.19 & 0.17 & 10 & 5 & 10 \\
\hline Ethanol & 39000 & 0.79 & 5.7 & -114.1 & 325 & 431.4 & 2752 & 0.15 & 0.22 & 10 & 10 & 10 \\
\hline Propanol & 67882 & 0.81 & 1.99 & -126.2 & 326 & 436.8 & 2774 & 0.029 & 0.25 & 10 & 5 & 10 \\
\hline Butanol & 8000 & 0.81 & 0.6 & -89.5 & 328 & 442.9 & 2797 & 0.075 & 0.27 & 10 & 5 & 10 \\
\hline Pentanol & 14000 & 0.81 & 0.4 & -79 & 329 & 445.6 & 2803 & 0.029 & 0.28 & 10 & 5 & 10 \\
\hline
\end{tabular}

For ethanol ignitability scores a 10 because from literature [13][14] it is known that it is possible to make ethanol spontaneously ignite with hydrogen peroxide by adding a catalyst to the fuel. For the other alcohols it is unknown if this works as well.

The measures of effectiveness of the alkanes are presented in Table 12. Ethane, propane and butane are liquified gases, which explains the high vapor pressures. Only pentane is liquid at ambient condition. Because of the high vapor pressure the HRI values are high.

Table 12 Measures of effectiveness for alkanes as fuel and hydrogen peroxide as oxidizer at stoichiometric mixture ratio

\begin{tabular}{|c|c|c|c|c|c|c|c|c|c|c|c|c|}
\hline & \multicolumn{3}{|c|}{ Properties } & \multicolumn{9}{|c|}{ Measures of effectiveness } \\
\hline Fuel & $\begin{array}{l}\mathrm{LC}_{50} \\
\text { ppm }\end{array}$ & $\begin{array}{c}\rho_{\text {fuel }} \\
\mathrm{g} / \mathrm{cm}^{3}\end{array}$ & $\begin{array}{c}\text { Pvap } \\
\text { kPa }\end{array}$ & $\begin{array}{l}\mathrm{T}_{\mathrm{F}} \\
{ }^{\circ} \mathrm{C}\end{array}$ & $\begin{array}{c}I_{s p} \\
s\end{array}$ & ${ }^{\rho I_{\text {sp }}}{ }_{\text {kg.s.m }}$ & $\begin{array}{l}\mathbf{T}_{\mathbf{C}} \\
\mathbf{K}\end{array}$ & $\begin{array}{c}\text { HRI } \\
-\end{array}$ & $\begin{array}{c}C_{\text {frac }} \\
-\end{array}$ & $\begin{array}{l}\text { A. } \\
-\end{array}$ & $\begin{array}{c}\text { Ign. } \\
-\end{array}$ & $\begin{array}{l}\text { U. } \\
-\end{array}$ \\
\hline Ethane & 658 & 0.54 & 3845 & -172 & 334 & 446.1 & 2826 & 164.8 & 0.25 & 10 & 5 & 0 \\
\hline Propane & 14000 & 0.51 & 853 & -187.7 & 334 & 443.5 & 2835 & 26.2 & 0.27 & 10 & 5 & 0 \\
\hline Butane & 10325 & 0.57 & 203 & -140 & 334 & 447.2 & 2838 & 21.7 & 0.29 & 10 & 5 & 0 \\
\hline Pentane & 123351 & 0.63 & 57 & -130 & 333 & 446.7 & 2845 & 4.6 & 0.29 & 10 & 5 & 0 \\
\hline
\end{tabular}

From the group of alkenes (Table 12) only pentane is liquid at ambient condition.

Table 13 Measures of effectiveness for alkenes as fuel and hydrogen peroxide as oxidizer at stoichiometric mixture ratio

\begin{tabular}{|c|c|c|c|c|c|c|c|c|c|c|c|c|}
\hline & \multicolumn{3}{|c|}{ Properties } & \multicolumn{9}{|c|}{ Measures of effectiveness } \\
\hline Fuel & $\begin{array}{l}\mathrm{LC}_{50} \\
\text { ppm }\end{array}$ & $\begin{array}{c}\rho_{\text {fuel }} \\
\mathrm{g} / \mathrm{cm}^{3}\end{array}$ & $\begin{array}{l}P_{\text {vap }} \\
\mathbf{k P a}\end{array}$ & $\begin{array}{l}T_{F} \\
{ }^{\circ} \mathrm{C}\end{array}$ & $\begin{array}{l}I_{s p} \\
s\end{array}$ & $\begin{array}{c}\rho I_{\text {sp }} \\
\text { kg.s. } \text { m }^{-3}\end{array}$ & $\begin{array}{l}\mathbf{T}_{\mathrm{C}} \\
\mathbf{K}\end{array}$ & $\begin{array}{c}\text { TRI } \\
-\end{array}$ & $\begin{array}{c}\mathrm{C}_{\mathrm{frac}} \\
-\end{array}$ & $\begin{array}{l}\text { A. } \\
-\end{array}$ & $\begin{array}{c}\text { Ign. } \\
-\end{array}$ & $\begin{array}{c}\text { U. } \\
-\end{array}$ \\
\hline Ethene & 57000 & 0.58 & 4590 & -169 & 340 & 450.8 & 2938 & 81 & 0.33 & 10 & 5 & 0 \\
\hline Propene & 658 & 0.61 & 1017 & -185 & 336 & 453.3 & 2884 & 1546 & 0.33 & 10 & 5 & 0 \\
\hline Butene & 426 & 0.62 & 263 & -185 & 335 & 447.9 & 2886 & 617 & 0.33 & 10 & 5 & 0 \\
\hline Pentene & 61000 & 0.64 & 58 & -165 & 334 & 447.5 & 2889 & 0.95 & 0.33 & 10 & 5 & 0 \\
\hline
\end{tabular}

The measures of effectiveness for the group of alkynes are given in Table 14 only pentane is liquid at ambient condition. For the unknow $\mathrm{LC}_{50}$ values $500 \mathrm{ppm}$ (lowest value for a HGS class 3 specie) is used to determine the measures of effectiveness. Because this unknown value the uncertainty in 
compliancy to the requirements is increased. For the unknown Freezing temperature of butyne the lowest value to be compliant to the requirements is taken $\left(-10^{\circ} \mathrm{C}\right)$.

Table 14 Measures of effectiveness for alkynes as fuel and hydrogen peroxide as oxidizer at stoichiometric mixture ratio

\begin{tabular}{|c|c|c|c|c|c|c|c|c|c|c|c|c|}
\hline & \multicolumn{3}{|c|}{ Properties } & \multicolumn{9}{|c|}{ Measures of effectiveness } \\
\hline Fuel & $\begin{array}{l}\mathrm{LC}_{50} \\
\text { ppm }\end{array}$ & $\begin{array}{c}\rho_{\text {fuel }} \\
\mathbf{g} / \mathbf{c m}^{3}\end{array}$ & $\begin{array}{l}P_{\text {vap }} \\
\text { kPa }\end{array}$ & $\begin{array}{l}\mathrm{T}_{\mathrm{F}} \\
{ }^{\circ} \mathrm{C}\end{array}$ & $\begin{array}{l}I_{s p} \\
s\end{array}$ & $\begin{array}{c}\rho I_{\text {sp }} \\
\text { kg.s.m }{ }^{-3}\end{array}$ & $\begin{array}{l}\mathbf{T}_{\mathrm{C}} \\
\mathbf{K}\end{array}$ & $\begin{array}{c}\text { TRI } \\
-\end{array}$ & $\begin{array}{c}\mathrm{C}_{\text {frac }} \\
-\end{array}$ & $\begin{array}{l}\text { A. } \\
-\end{array}$ & $\begin{array}{c}\text { Ign. } \\
-\end{array}$ & $\begin{array}{l}\text { U. } \\
-\end{array}$ \\
\hline Propyne & $?$ & 0.53 & 530 & -103 & 342 & 447.7 & 3006 & 112.7 & 0.43 & 10 & 5 & 4 \\
\hline Butyne & ? & 0.691 & 110 & $?$ & 339 & 453.8 & 2960 & 77.5 & 0.40 & 10 & 5 & 5 \\
\hline Pentyne & $?$ & 0.71 & 47 & -109 & 337 & 452.9 & 2939 & 62.2 & 0.38 & 10 & 5 & 4 \\
\hline
\end{tabular}

Finally, the MoE's of nitromethane are shown in Table 15.

Table 15 Measures of effectiveness for alkenes as fuel and hydrogen peroxide as oxidizer at stoichiometric mixture ratio

\begin{tabular}{|c|c|c|c|c|c|c|c|c|c|c|c|c|}
\hline & \multicolumn{3}{|c|}{ Properties } & \multicolumn{9}{|c|}{ Measures of effectiveness } \\
\hline Fuel & $\begin{array}{l}\mathrm{LC}_{50} \\
\text { ppm }\end{array}$ & $\begin{array}{c}\rho_{\text {fuel }} \\
\mathrm{g} / \mathrm{cm}^{3}\end{array}$ & $\begin{array}{l}P_{\text {vap }} \\
\mathbf{k P a}\end{array}$ & $\begin{array}{l}\mathrm{T}_{\mathrm{F}} \\
{ }^{\circ} \mathrm{C}\end{array}$ & $\begin{array}{l}I_{s p} \\
s\end{array}$ & $\begin{array}{c}\rho I_{\text {sp }} \\
\text { kg.s.m }\end{array}$ & $\begin{array}{l}\mathbf{T}_{\mathrm{C}} \\
\mathbf{K}\end{array}$ & $\begin{array}{c}\text { TRI } \\
-\end{array}$ & $\mathrm{C}_{\mathrm{frac}}$ & $\begin{array}{l}\text { A. } \\
-\end{array}$ & $\begin{array}{c}\text { Ign. } \\
-\end{array}$ & $\begin{array}{l}\text { U. } \\
-\end{array}$ \\
\hline $\begin{array}{l}\text { Nitrome- } \\
\text { thane }\end{array}$ & 3333 & 1.1371 & 3.7 & -28.38 & 325 & 415.9 & 2905 & 2.7 & 0.14 & 10 & 5 & 0 \\
\hline
\end{tabular}

For the fuels, the trade-off was performed identical as for the oxidizers and only the result of the fuel trade-off for the three scenario's is presented in Table 16. In this table the color of the cell is a measure of the trade-off score. The highest score has the lightest color.

In the balanced scenario, ethanol, propane or ethene may be the fuel of choice. Ethanol scores good on ignitibility and moderate flame temperature while for the higher hydrocarbons the performance is high.

For the maximum performance scenario ethene is the best choice. In this scenario the alcohols perform less than the hydrocarbons.

In case of a conservative scenario, ethanol is a good choice. The alkyne score not good because the uncertainty in meeting the requirements.

Nitromethane was identified as a promising monopropellant, but the trade-off for bipropellant fuels shows that nitromethane is not an attractive fuel for a bipropellant propulsion system.

It is concluded that there is not one fuel universally the best. Which fuel is 'the best' depends on the trade-off scenario. If a replacement for MMH is needed within a time frame of a few years the propellant of choice is ethanol because of the high score in the conservative scenario. The fuel can be made hypergolic, has a low health risk index, has acceptable performance and there are not many development risks expected. If performance is the development driver then ethene may be the propellant of choice. Of the fuels investigated it scores high on the performance MoE's and still the development risks are limited. The health risk index however is higher than that of ethanol mainly due to the high vapor pressure.

Taken in to account all three scenario's ethanol offers the most potential as a replacement of the $\mathrm{MMH}$ fuel for space propulsion, especially if hypergolic ignition is an important criteria. For this study, 'hypergolic ethanol' is selected as bipropellant fuel. 
Table 16 Results of the fuel trade-off, the highest possible score is 1

\begin{tabular}{|c|c|c|c|}
\cline { 2 - 4 } \multicolumn{1}{c|}{} & Balanced & Maximum performance & Conservative \\
\hline \multirow{2}{*}{$\begin{array}{c}\text { Methanol } \\
\text { Ethanol }\end{array}$} & 0.61 & 0.45 & 0.69 \\
\cline { 2 - 4 } & 0.75 & 0.68 & 0.83 \\
\hline Propanol & 0.69 & 0.62 & 0.74 \\
\hline Butanol & 0.68 & 0.66 & 0.74 \\
\hline Pentanol & 0.69 & 0.67 & 0.74 \\
\hline Ethane & 0.67 & 0.69 & 0.59 \\
\hline Propane & 0.74 & 0.72 & 0.75 \\
\hline Butane & 0.72 & 0.73 & 0.74 \\
\hline Pentane & 0.72 & 0.72 & 0.76 \\
\hline Ethene & 0.74 & 0.78 & 0.75 \\
\cline { 2 - 4 } & 0.69 & 0.75 & 0.63 \\
\hline Propene & 0.67 & 0.71 & 0.63 \\
\hline Butene & 0.72 & 0.73 & 0.75 \\
\hline Pentene & 0.56 & 0.69 & 0.53 \\
\hline Propyne & 0.56 & 0.70 & 0.57 \\
\hline Butyne & 0.62 & 0.72 & 0.61 \\
\hline Pentyne & 0.54 & 0.45 & \\
\hline Nitromethane & & & 0.67 \\
\hline
\end{tabular}

\section{PROPELLANT VERIFICATION}

In previous paragraph a monopropellant an bipropellant was selected as green replacement for the current space propulsion propellants. Technology gaps for both, monopropellant and bipropellant, are identified. For nitromethane as monopropellant the technology gap is the initiation of the decomposition reaction and sustained decomposition. For the ethanol/hydrogen peroxide propellant the technology gap is on a hypergolic fuel formulation. Both technology gaps were addressed by means of initial engine firings. These test were not meant to verify engine performance, these objective of these tests was to investigate the technology gaps as a second step in to the development of a green mono and bipropellant alternative.

\subsection{Mono-propellant verification}

The monopropellant assessment in Paragraph 3.4 showed that nitromethane is the most promising candidate to replace hydrazine. Despite its high potential in terms of specific impulse and (low) toxicity, very little research has been published that focused on nitromethane as a monopropellant for space 
propulsion applications. In the 1950s, a research on nitromethane was conducted by H.M. Kindsvater, who was working for Aerojet[12]. His report mentions several difficulties with the thermal decomposition of nitromethane, one of which is the slow decomposition rate and the consequently large characteristic chamber lengths $\left(\mathrm{L}^{*}\right)$ required to achieve acceptable combustion quality. However, Kindsvater also showed that certain oxygen rich additives can decrease the characteristic chamber length dramatically. Yetter [15] conducted hot fire tests with a small nitromethane thruster. During these experiments, a $108 \mathrm{~mm}^{3}$ combustor was initially ignited on a methane-oxygen flame, operating at an equivalence ratio of 0.5 . Liquid nitromethane was injected tangentially through a separate inlet port at the entrance of the combustor. Once a nitromethane flame was established, the methane flow was shut-off and the oxygen flow was gradually decreased until the nitromethane was decomposing on its own. At low pressures $(-1 \mathrm{bar})$, the nitromethane decomposition could not be sustained without a small oxygen flow ( $>6 \mathrm{vol} \%)$. Also, several groups have studied the burning behavior of liquid nitromethane under high pressure conditions (30-1500 bar) [16]. The experimental side of this research typically involved a liquid strand burner setup in which a column of liquid nitromethane was ignited to study the regression rate of the propellant at a specific pressure. During these experiments, all groups reported ignition difficulties of nitromethane, especially at low pressures ( $<42 \mathrm{bar}$ ). However, it should be noted that the conditions in a liquid strand burner are very different from the conditions in a typical thruster, where the propellant is atomized and the heat transfer from the igniter to the propellant is much more efficient. Nevertheless, the ignitability of nitromethane monopropellant is an issue, especially at low pressures.

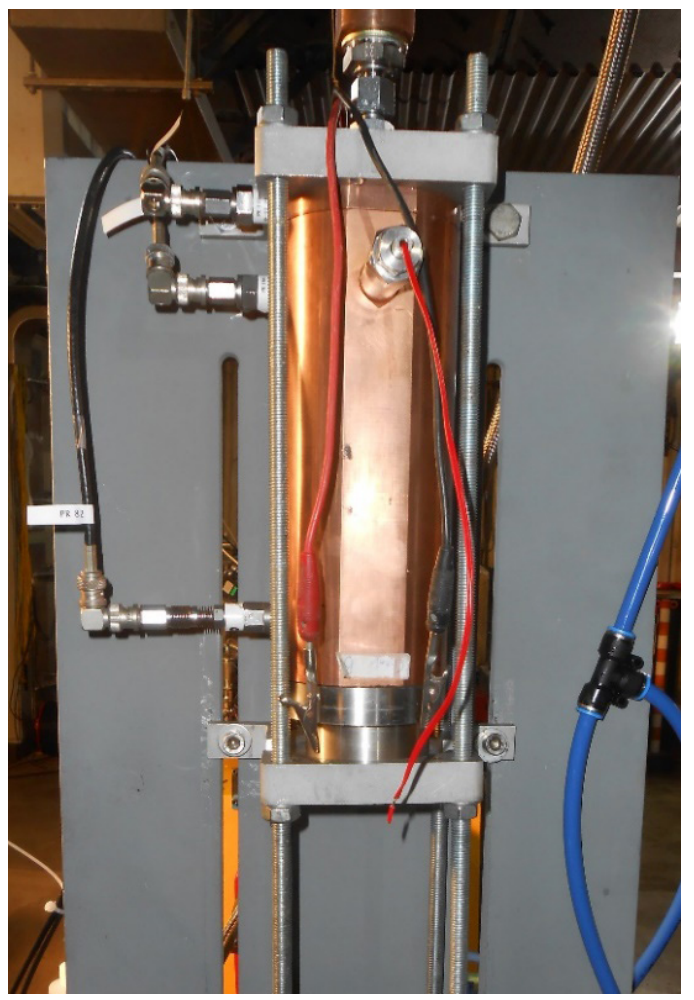

Figure $2100 \mathrm{~N}$ monopropellant test engine for the nitromethane engine firings 
Because of the slow decomposition rate and the unfavourable ignition characteristics reported in literature, it was concluded that pure nitromethane is most likely unsuitable as a monopropellant for space propulsion applications. However, by adding certain oxidizer rich compounds to the nitromethane, the ignitability and decomposition rate could be improved substantially. Therefore, a nitromethane based monopropellant is still considered a promising option. As a first step in the development of such a propellant, TNO started an experimental investigation into the decomposition rate and ignitability of pure nitromethane, in a representative thruster configuration. The purpose of this investigation was to establish a baseline for future propellant research, which can later be used to objectively compare the effect of various additives on the decomposition rate and ignitability. The objectives of the investigation were:

1. To determine if pure nitromethane can be thermally ignited in a representative thruster configuration.

2. To establish a baseline for the required ignition energy in terms of booster mass

3. To determine the relationship between characteristic velocity $\left(\mathrm{C}^{*}\right)$, characteristic chamber length $\left(\mathrm{L}^{*}\right)$ and combustion chamber pressure $(\mathrm{Pc})$

A series of ignition tests were conducted, using a $100 \mathrm{~N}$ heat sink engine with a 3 element showerhead injector. The igniter was a reusable pyrogen igniter, loaded with a small amount of ammonium perchlorate propellant. The igniter power could be varied by loading different amounts of propellant in the igniter. A photograph of the setup is shown in Figure 2.

A total of 17 hot firing attempts were made, with booster masses varying between $0.25 \mathrm{~g}$ and $3.0 \mathrm{~g}$ and nitromethane start-up mass flows between 20 and $95 \mathrm{~g} / \mathrm{s}$. The pressure inside the combustion chamber at the moment the igniter firing was 1 bar. Only one test resulted in ignition of the nitromethane, but this ignition was associated with a high pressure peak in the combustion chamber, causing the stagnation and immediate extinction of the nitromethane flow. This ignition event could not be reproduced. As none of the tests resulted in sustained decomposition of the nitromethane flow, test objectives 2 and 3 could not be addressed in this test campaign.

Post analysis of the test data revealed that the ignition sequence was not very reproducible, causing the igniter to fire at different moments during the start-up transient of the nitromethane flow. This was the most likely reason for not being able to reproduce the observed ignition event. Nevertheless, it was still concluded that pure nitromethane is very difficult to ignite at a pressure of 1 bar.

The next step in the development of a nitromethane based propellant will be to improve the design of the test setup to obtain a more reproducible start up behaviour of the engine. With the improved setup, part of the tests with pure nitromethane will be repeated in an attempt to reproduce the observed ignition event. After that, various compositions of nitromethane with different oxygen rich additives will be tested.

\subsection{Bi-propellant verification tests}

As possible green propellant combination for the replacement of $\mathrm{MMH} / \mathrm{MON}$ propellant, the hydrogen peroxide as oxidizer and ethanol as fuel was selected. This combination of propellants is investigated many times already but never developed towards an in space propulsion system. The advantage of this propellant is that it can be initiated by all three types of ignition strategies:

1. external igniter

2. catalytic decomposition of hydrogen peroxide as ignition source

3. hypergolic ignition 
At TNO ethanol is successfully ignited by decomposed hydrogen peroxide in an igniter configuration. A drawback of this initiation method is that the catalytic bed needs to be heated before it decomposes hydrogen peroxide efficiently. The most attractive ignition method for in space propulsion remains hypergolic ignition, comparable to that of the current state of the art bi-propellant space propulsion systems.

Ethanol mixture to establish a catalytic induced hypergolic reaction with hydrogen peroxide.

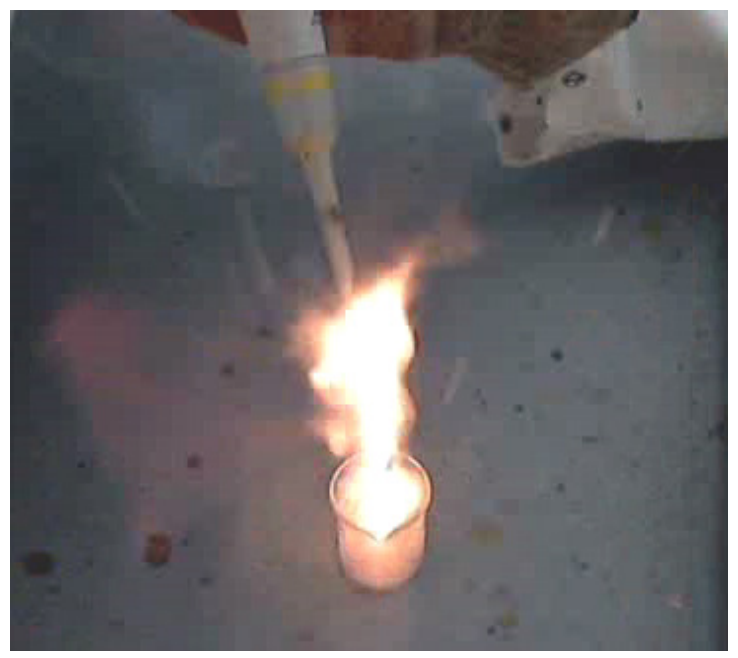

Figure 3 ,Hypergolic' reaction between hydrogen peroxide and TNO fuel PT28

Ethanol in itself is not hypergolic with hydrogen peroxide, but the addition of a catalyst, dissolved in the ethanol, may result in a fuel capable of decomposing hydrogen peroxide and initiating a combustion reaction. From literature several studies were found in to adding catalysts to ethanol to establish a hypergolic reaction with hydrogen peroxide[13][14].

Taken the results from literature TNO conducted a study in to an ethanol mixture that catalytically induced a hypergolic reaction with hydrogen peroxide. This study is outside the scope of this paper, only the main results are presented in this paper. The resulting ethanol mixture is used for the bipropellant verification test firings.

As catalyst for hydrogen peroxide, serval elements within the group of the so called "transition metals" are very effective; for example silver and manganese are well known catalysts. By means of screening tests salts of these transition metals, dissolved in ethanol, were tested on its capability to start a combustion reaction with hydrogen peroxide at room temperature. Some of the mixtures were capable igniting hydrogen peroxide and ethanol when brought together.

The screening tests were performed using a fume hood in which a small beaker was placed. In this beaker a small amount of $90 \%$ concentrated hydrogen peroxide was present. By means of a pipet fuel was added and the effect was observed. The effect ranged from 'no reaction' to 'explosive reaction'.

It was found that the most promising catalyst included Iron(III) ions. Figure 3 shows one of the screening tests performed at TNO with an Iron(III) salt dissolved in ethanol. During this test the propellant was at room temperature and the ignition delay was a few milliseconds. This fuel 'PT28' was selected for engine verification tests. It must be noted that the composition of PT28 is a functional composition and not an optimized composition. 


\section{Verification tests}

The ethanol based fuel PT28 was verified on its capability to spontaneous ignite with hydrogen peroxide was tested in a $200 \mathrm{~N}$ test engine. The propellant injector was an impinging injector with a central oxidizer orifice and four fuel orifices around the central orifice. The injector was designed to generate a pressure drop of approximately 5 bar at an oxidizer and fuel mass flow of $25.6 \mathrm{~g} \mathrm{~s}^{-1}$ and $6.5 \mathrm{~g} \mathrm{~s}^{-1}$ respectively. In Figure $4 \mathrm{a}$ functional test of the fuel elements of the injector is shown. The test engine has graphite inserts which defines the internal geometry of the motor. Graphite was selected as the insert material in order to cope with the expected high combustion temperatures $(>2500 \mathrm{~K})$ and to minimize heat losses (graphite is a moderate thermal insulator). With the segmented engine design the effects the engine $L^{*}$ characteristic can be studied.

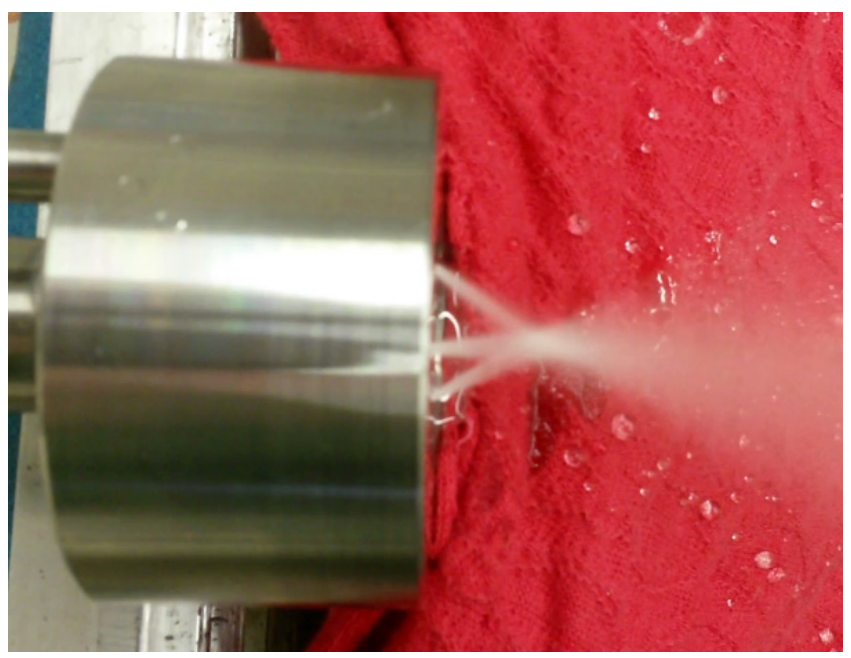

Figure 4: Fuel elements functional test with water and at ambient condition of the bi-propellant injector head

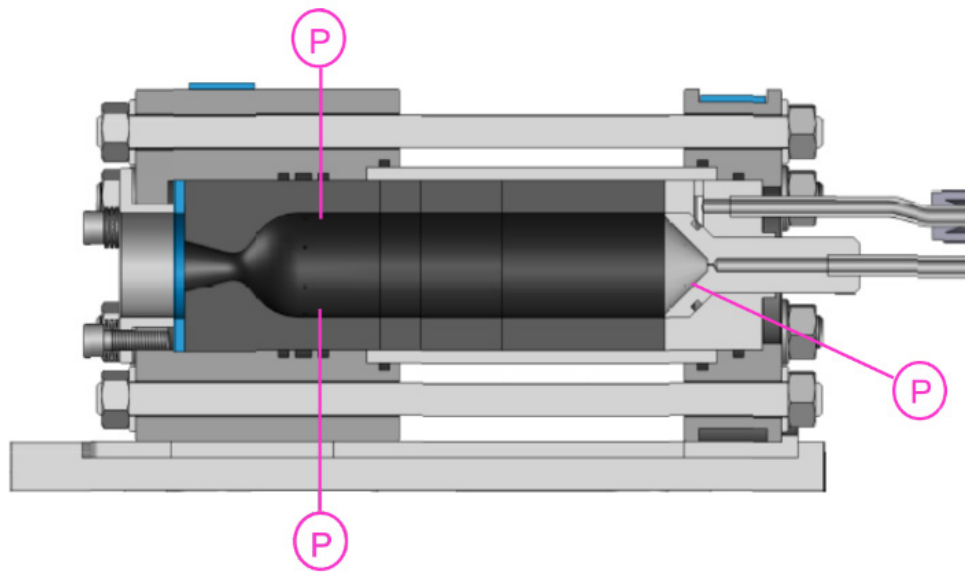

Figure 5: $200 \mathrm{~N}$ Test engine with carbon combustion chamber 


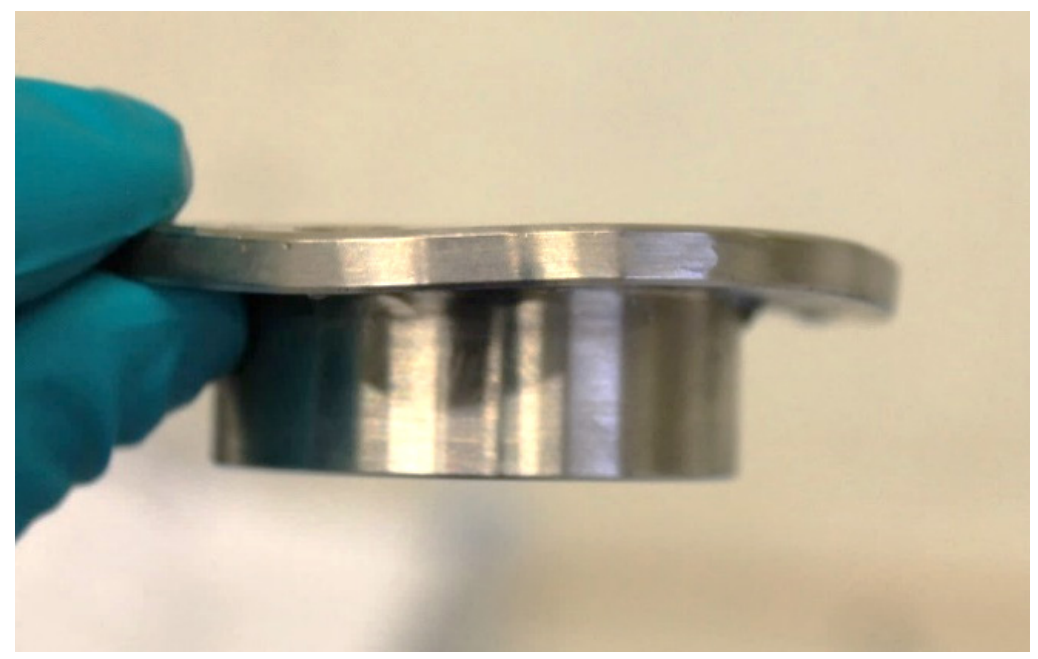

Figure 6: Deformation of engine closure cap after engine misfiring

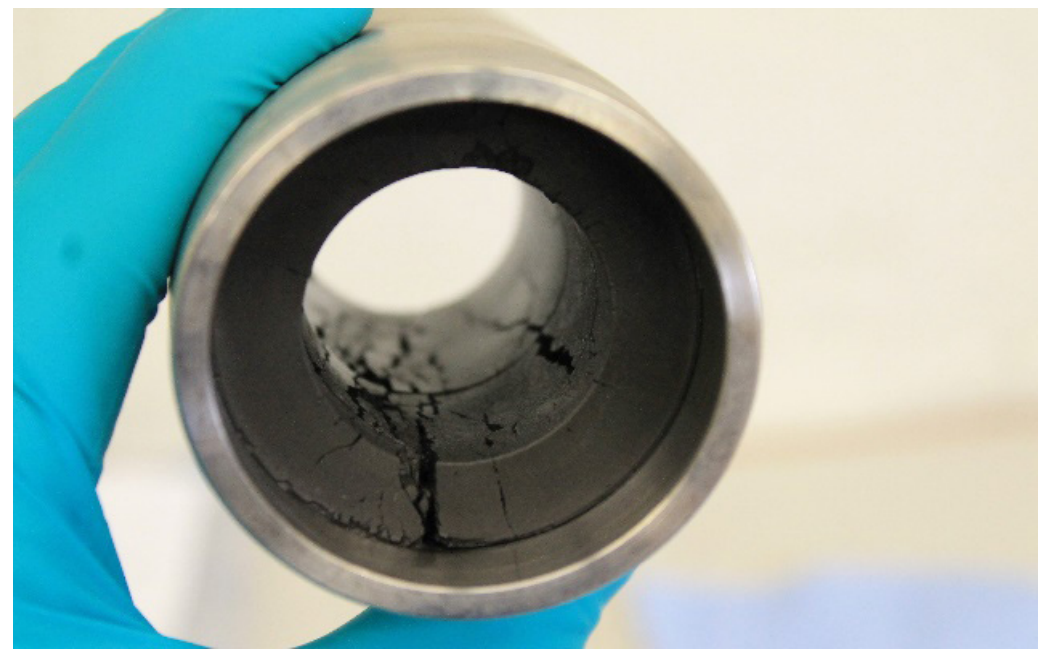

Figure 7: Fractured carbon chamber segment after misfiring

Tests were performed with this test engine, unfortunately not all tests were successful. During tests in a horizontal test setup some problems with timing of the propellant flow occurred. This timing problem resulted in to a small lead time of oxidizer after which the fuel flow follows. In the horizontal test setup the hydrogen peroxide oxidizer was captured in its liquid phase inside the engine and at the moment the fuel was injected the propellant ignited and the excess of hydrogen peroxide already in the engine decomposed. The result of this was explosive decomposition/combustion and a pressure peak well outside the design pressure range of the engine. This heavily damaged the engine. Figure 6 and Figure 7 show the effect of this misfiring 


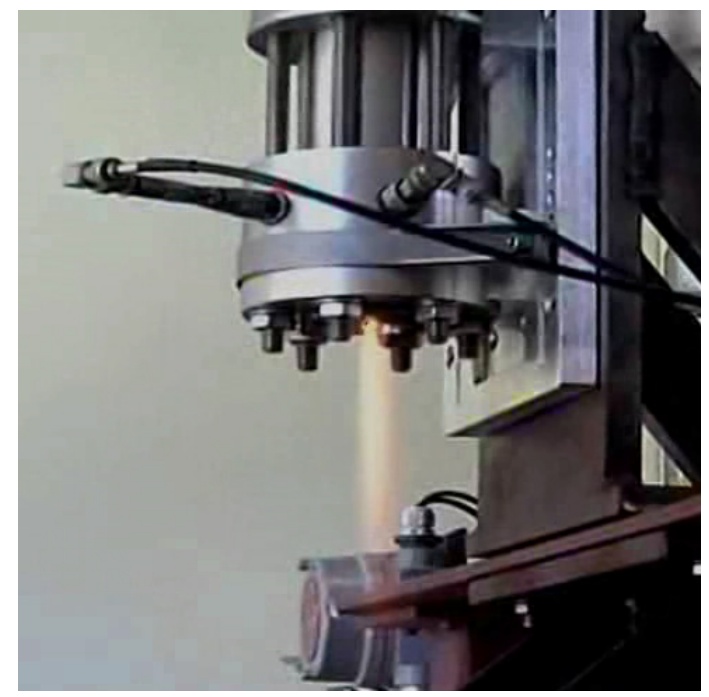

Figure 8 Successful firing of the hypergolic PT28 fuel with hydrogen peroxide oxidizer

To overcome the buildup of one of the propellant constituents inside the engine due to timing problems the horizontal test setup was changed in to a vertical test setup. After this change in setup a successful engine test with propellant PT28 was conducted (Figure 8).

Although the ignition of the test engine was successful, the combustion was irregular and the recorded pressure data was too erratic for evaluation of the propellant performance parameters. Modifications to the fuel are required for smooth sustained combustion to evaluate the propellant performance. In spite of this, the tests successfully demonstrated that ethanol can be made hypergolic with hydrogen peroxide to serve as an attractive green propellant for space propulsion. Further optimization of the fuel is required for obtaining predictable sustained combustion.

\section{CONCLUSIONS}

A study was described in to the search for an acceptable green propellant for space propulsion application. A monopropellant and bipropellant alternative was found by means of a tradeoff study. In the tradeoff study measures of effectiveness were used to identify the propellant that has the most benefits in excess of the minimal set of requirements. As monopropellant nitromethane was selected and as bipropellant ethanol as fuel and hydrogen peroxide as oxidizer. The technology gaps identified for both propellants were addressed by means of initial engine firings. With nitromethane as monopropellant initiation and sustained combustion problems were identified and reproduced. A possible solution is to dissolve a small amount of oxidizer in the nitromethane to improve its ignition capability and reducing the required engine characteristic length. For the bipropellant additives to the fuel were selected which makes ethanol hypergolic with hydrogen peroxide, Hypergolic ignition of the test engine was successfully demonstrated, however optimization of the mixture is required to obtained predictable combustion behavior. 


\section{BIBLIOGRAPHY}

[1] ECHA, 2011, "Inclusion of Substances of Very High Concern in the Candidate List", ED/31/2011, https://echa.europa.eu/documents/10162/c5b972a9-f57f-4fd5-8177-04b4e46c5e93

[2] ECHA, 2015, "Opinion proposing harmonised classification and labelling at EU level of Methylhydrazine", CLH-O-0000001412-86-75/F https:/echa.europa.eu/documents/10162/091dd1932571-417d-b980-7ee4f0598e54

[3] Tereza Pultarova, 2017, "Hydrazine ban could cost Europe's space industry billions", Spacenews, http://spacenews.com/hydrazine-ban-could-cost-europes-space-industry-billions/

[4] United Nations, 2011, "Globally Harmonized System of Classification and Labeling of Chemicals (GHS), Fourth revised edition”, ST/SG/AC.10/30/Rev.4

[5] Andreas Gernoth, 2016, "Statement of Work, Assessment of high performance green propellants”, AO8634, ESA-TRP-TECMPC-SOW-001891

[6] Gordon, S. Computer program for calculation of complex chemical equilibrium compositions, rocket performance, incident and reflected shocks and Chapman-Jouguet detonations. s.l. : NASA publication SP-273, 1976. NASA publication SP-273.

[7] McBride, B.J. Computer program for the calculation of complex chemical equilibrium compositions and applications: Users manual and program description. s.l. : NASA reference publication 1311, 1996.

[8] Kiyoshi Otsuka, Shoji Kobayashi, Sakae Takenaka, 2000, "Catalytic decomposition of light alkanes, alkenes and acetylene over Ni/SiO2”, Applied Catalysis A: General 210 (2001) 371-379

[9] Anders Larsson and Niklas Wingborg,2011,"Green Propellants Based on Ammonium Dinitramide (ADN)”, Advances in Spacecraft Technologies (p139-156), ISBN 978-953-307-551-8

[10] Tadeusz Urbanski, 1964," Chemistry and Technology of Explosives Vol. I", Pergamon press, PWN-Polish scientific publishers

[11] "Electronic Code of Federal Regulations, e-CFR data is current as of November 15, 2017", https://www.ecfr.gov/cgi-bin/text-idx?SID=4a5cb15c53be897dc59f5ea40636a2a2\&mc=true \&n ode $=$ sp49.2.172.b\&rgn $=\operatorname{div} 6$

[12] H.M. Kindsvater, K.K. Kendall, K.H. Mueller, P.P. Datner,1951, "Research on Nitromethane". Aeroject Engineering Cooperation, Report no. 493.

[13] Brian M. Melof and Mark C. Grubelich,2000,” Investigation of Hypergolic Fuels with Hydrogen Peroxide", 3rd International Hydrogen Peroxide Propulsion Conference, SAND2000-2842C

[14] Palmer, R. K. \& Rusek, J. J., 2004,’Low-Toxicity Reactive Hypergolic Fuels for Use with Hydrogen Peroxide", 2nd International Conference on Green Propellants for Space Propulsion (ESA SP-557). 7-8 June 2004

[15] R. Yetter, "Combustion issues and approaches for chemical microthrusters," International journal of Energetic Materials and Chemical Propulsion, 2007.

[16] J. Boyer, "Combustion characteristics and flame structure of nitromethane liquid monopropellant,” Penn State University, 2005. 


\section{BADANIA NAD EKONAPĘDEM W TNO W HOLANDII}

\section{Streszczenie}

W niniejszym artykule opisano wyniki najnowszych teoretycznych i eksperymentalnych badań Holenderskiejj Organizacji Stosowanych Badań Naukowych (TNO) na rzecz ekologicznych zamienników hydrazyny, pochodnych hydrazyny i tetratlenku diazotu, jako materiałów do napędu rakietowego. Celem badań była identyfikacja materiałów napędowych, mogących osiągnąć lepsze wyniki niż obecne paliwa rakietowe i będąc jednocześnie mniej niebezpiecznymi dla ludzi i środowiska. Zadano dwa typy materiałów pędnych, tak zwane „monopropellant” i „bipropellant”. W pierwszej części artykułu omówiono wybór materiału pędnego. Nitrometan okazał się najbardziej obiecującym materiałem typu „monopropellant”. Jako „bipropellant” wybrano połączenie nadtlenku wodoru (HP) i etanolu, w którym etanol zmodyfikowano hypergolicznie nadtlenkiem wodoru. W drugiej część artykułu opisano eksperymentalną weryfikację zastosowania materiałów napędowych za pomocą testów silnika. Pomimo początkowych problemów z rozkładem nitrometanu, udowodniono hipergoliczny zapłon nadtlenku wodoru i zademonstrowano „bipropellant” etanolowy.

Słowa kluczowe: napęd ekologiczny, monopropellant, bipropellant, nadtlenek wodoru, nitrometan. 